\title{
Improvement Analyses of a Photovoltaic System Controlled by the MPPT Command Perturb and Observe
}

\author{
Abdelhadi El Moudden, \\ Ikram Bohadria \\ Team Analysis and Command \\ of Electrical Energy Systems \\ (ACSEE) \\ LISER - Laboratory \\ ENSEM, Hassan II University \\ Casablanca, Morocco
}

\author{
Abdelali Aarib, \\ Widad Driouich \\ Team Analysis and Command \\ of Electrical Energy Systems \\ (ACSEE) \\ LISER - Laboratory \\ ENSEM, Hassan II University \\ Casablanca, Morocco
}

\author{
Abdelhamid Hmidat \\ Electrical Systems Team \\ ENSEM, Hassan II University \\ BP 8118, Oasis, \\ Casablanca, Morocco
}

\begin{abstract}
This paper will discuss the study, analysis and simulation of a photovoltaic (PV) electrical system performance adapted to a Maximum Power Point Tracking (MPPT) command for ensuring the pursuit of the maximum power supplied by the generator.
\end{abstract}

To attain this purpose, the focus was on obtaining a system which presents a better adaptation between its various components: Photovoltaic generator (GPV) and load.

The proposed approach is a (MPPT) command based on the algorithm perturb and observe, the role of which is to fix the optimal tension to the (GPV) output.

The control carried out allows searching for the Maximum Power Point (MPP). The results obtained show that the controller used manages to force the system to operate at a maximum output power of (GPV) independently of the weather conditions and of the variation of the load.

In this analysis, the conceived system is a (GPV) of the type SP75 producing, under standard test conditions (STC), a peak power of $75 \mathrm{~W}$, an optimal current of $4.41 \mathrm{~A}$ and an optimal tension of $17.2 \mathrm{~V}$.

\section{Keywords}

MPPT, MPP, Photovoltaic System, Photovoltaic Generator, Perturb \& Observe, Command, GPV, PV.

\section{INTRODUCTION}

Following the example of the diverse existing renewable energy, the photovoltaic energy is extremely interesting on the one hand by its abundance and on the other, by absence of climatic and noise pollution. To be used for various applications and to satisfy the economic constraints, the conception and implementation of (PV) systems are necessary and raise at present numerous problems. The realized PV system must be robust, reliable and presenting a high efficiency [1].

For a photovoltaic system, the variation of illumination or the load induces a degradation of the power supplied by the (GPV) of the order of 50\%; in addition, the (GPV) no longer works in the optimum conditions [2]. For this, it is necessary to extract the maximum power from the (GPV) power available at the (GPV), and generally not drawn by the load. A good profitability of the (GPV) can be realized if it works at maximum power all the time. Now, the maximum power point varies according to several parameters as solar irradiation $\mathrm{G}$, the temperature $\mathrm{T}$ and the nature of the load. Regardless of weather conditions (temperature and irradiation), and the load, the control system of the converter sets the system up to the maximum operating point $\left(I_{\text {opt }}, V_{\text {opt }}\right)$ The generator may at any time have the power curve modified, as well as the optimal power. The (MPPT) controller must meet the requirement to seek the (MPP) and maintain a functioning around this point [3].

\section{EQUIVALENT CIRCUIT OF A PHOTOVOLTAIC CELL}

Regarding the behaviour of an actual solar cell, two parasitic resistances are taken into account for a more accurate description [4].

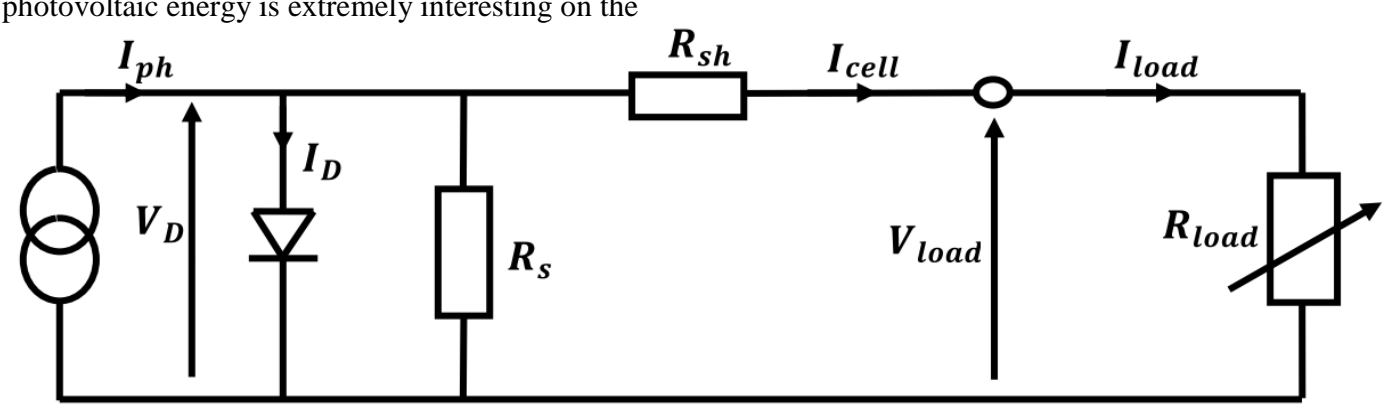

Fig 1 : Equivalent circuit of a solar cell [5]

Where :

$R_{s h}$ : Shunt resistance characterizing the leakage current on the surface of the cell due to the non-ideality of the PN junction and impurities near the junction.
$R_{S}$ : Series resistance representing the various contact resistances and the resistance of the semi-conductor. In practice, the parallel resistance $R_{S h}$ is very important (on the order of the mega ohm) and series resistance $R_{S}$ is very low 
(of the order of a few milli-ohms). With such an equivalent electric circuit:

$$
\begin{gathered}
I_{\text {cell }}=I_{p h}-I_{D}-\frac{V_{D}}{R_{s h}} \\
I_{D}=I_{S}\left(e^{\frac{V_{D}}{V_{t h}}}-1\right) \\
V_{D}=V_{\text {cell }}+R_{S} I_{\text {cell }}
\end{gathered}
$$

So the current delivered by the cell can be described as :

$$
I_{c e l l}=I_{p h}-I_{S}\left(e^{\left(V_{c e l l}+R_{S} I_{c e l l}\right) / V_{t h}}-1\right)-\frac{V_{\text {cell }}+R_{S} I_{c e l l}}{R_{\text {sh }}}
$$

Where :

$I_{\text {cell }}:$ Current delivered by the cell (A)

$I_{D}:$ Diode current (A)

$I_{\text {load }}:$ Current through the load (A)

$I_{p h}:$ Photo-current (A)

$I_{S}: \quad$ Saturation current (A)

$R_{\text {load }}$ : The load resistance $(\Omega)$

$R_{S}: \quad$ Resistance series $(\Omega)$

$R_{s h}: \quad$ Parallel resistance $(\Omega)$

$V_{\text {cell }}:$ Voltage at the cell terminals $(\mathrm{V})$
$V_{\text {load }}:$ Terminal voltage at the load $(\mathrm{V})$

$V_{o c}: \quad$ Open circuit voltage $(\mathrm{V})$

$V_{t h}: \quad$ Thermal voltage $(\mathrm{V})$

$V_{D}: \quad$ Diode voltage $(\mathrm{V})$

$P_{\text {max }}: \quad$ Maximum power of photovoltaic panel (W)

$I_{M P P}:$ The current maximum power point (A)

$V_{M P P}:$ The maximum power point voltage $(\mathrm{V})$

$P_{P V}: \quad$ The power of photovoltaic panel (W)

$R_{\text {Load }}$ : The resistance of the load $(\Omega)$

$V_{P V}: \quad$ Voltage generator $(\mathrm{V})$

$I_{P V}: \quad$ Current generator (A)

\section{PHOTOVOLTAIC SYSTEM}

A solar cell is a sensor consisting of a semi-conductor material which absorbs light energy and converts it into electrical current. The principle of functioning of this sensor involves the absorption properties of light radiation by the semi-conductor materials. So, the choice of materials used to design (PV) cells is made according to the physical properties of some of their electrons which can be released from their atoms when excited by photons in the solar spectrum and having certain amount energy according to their wave lengths. Once released, these loads move in the material forming overall a continuous electric current type (DC). The circulation of this current then gives rise to an electromotive force (emf) across the corresponding semi-conductor and the physical phenomenon called photovoltaic effect.

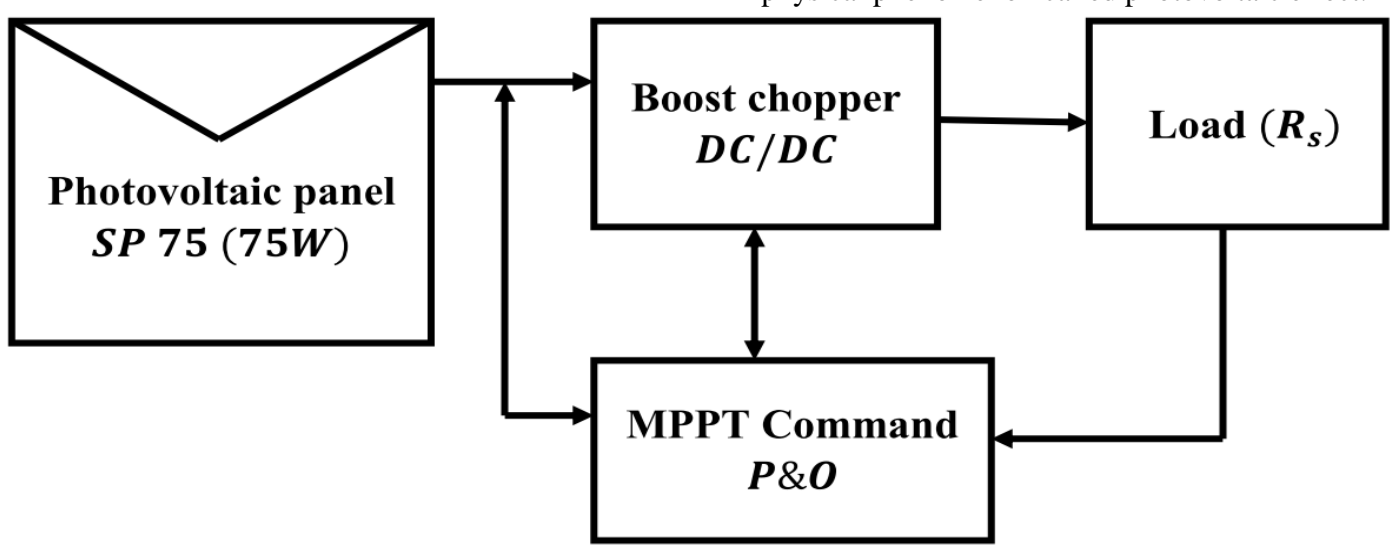

Fig 2 : PV System with MPPT [6]

The (MPPT) control is a functional organ of the (PV) system and allows searching for the optimum operating point of the (GPV) in the weather conditions and stable load.
Whatever type of command used [7][8][9], the principle of regulation is based on the automatic variation of the duty cycle $\alpha$ relating to the appropriate value to maximize the power output of the (PV) panel. 


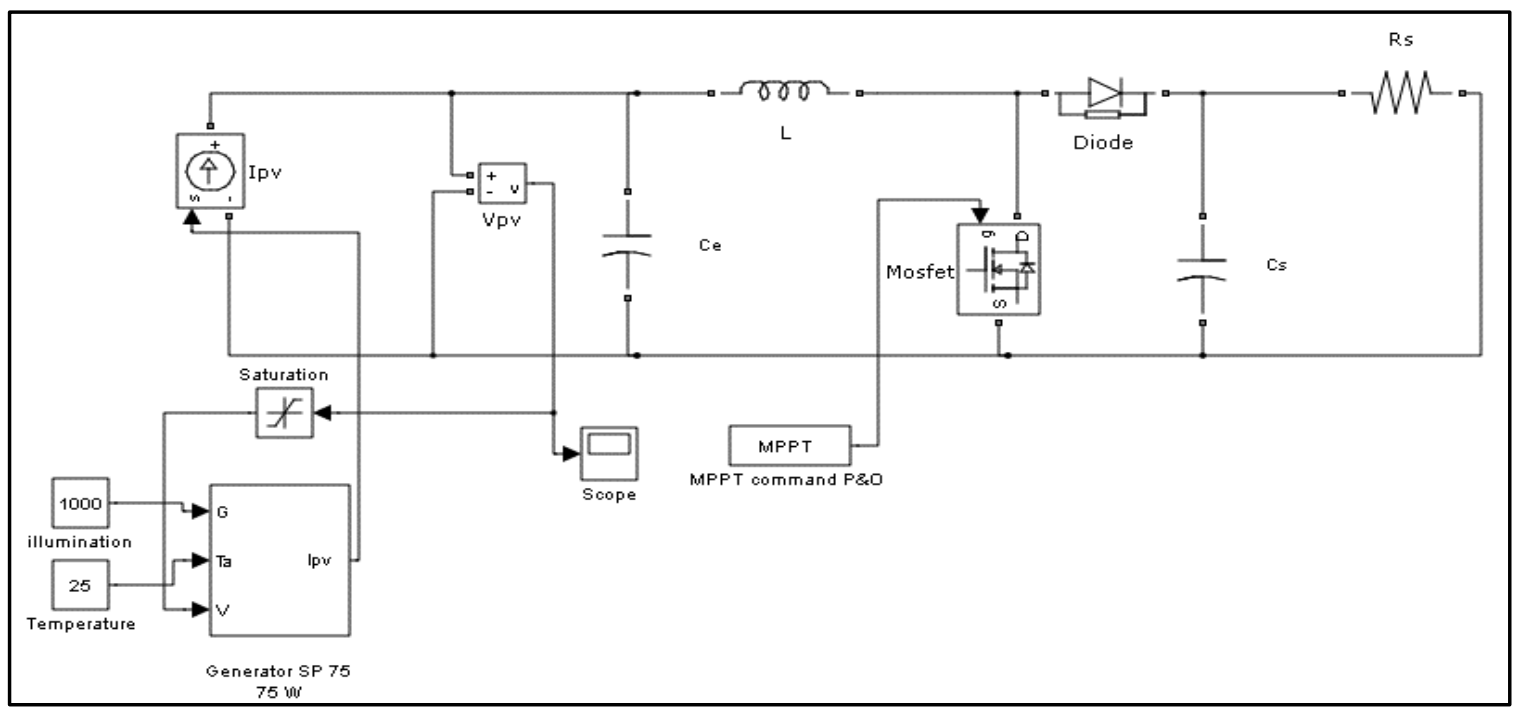

Fig 3 : The MPPT control of a photovoltaic panel using a boost converter in Matlab/Simulink [10]

The performance of this type of lift can reach $98 \%$, which allows losses of less than $0.5 \%$ on each active component, i.e., the self, the switch (here the MOS transistor), and diode. The remaining few (MPPT) are reserved for the control and command circuit. In general, the conduction operation continuous in the inductor is preferable from the view point of the effective intensity. This is all easier to achieve when the current is high. For low intensities (lower power consumption), the problem inevitably arises, but in this case, the losses are minimal because the latter are proportional to the current square. The corresponding effective intensity will estimate the losses in the various system components. For this, it is necessary to have a correct shape of the current [11].

\section{PERTURB \& OBSERVE (P\&O) MPPT ALGORITHM}

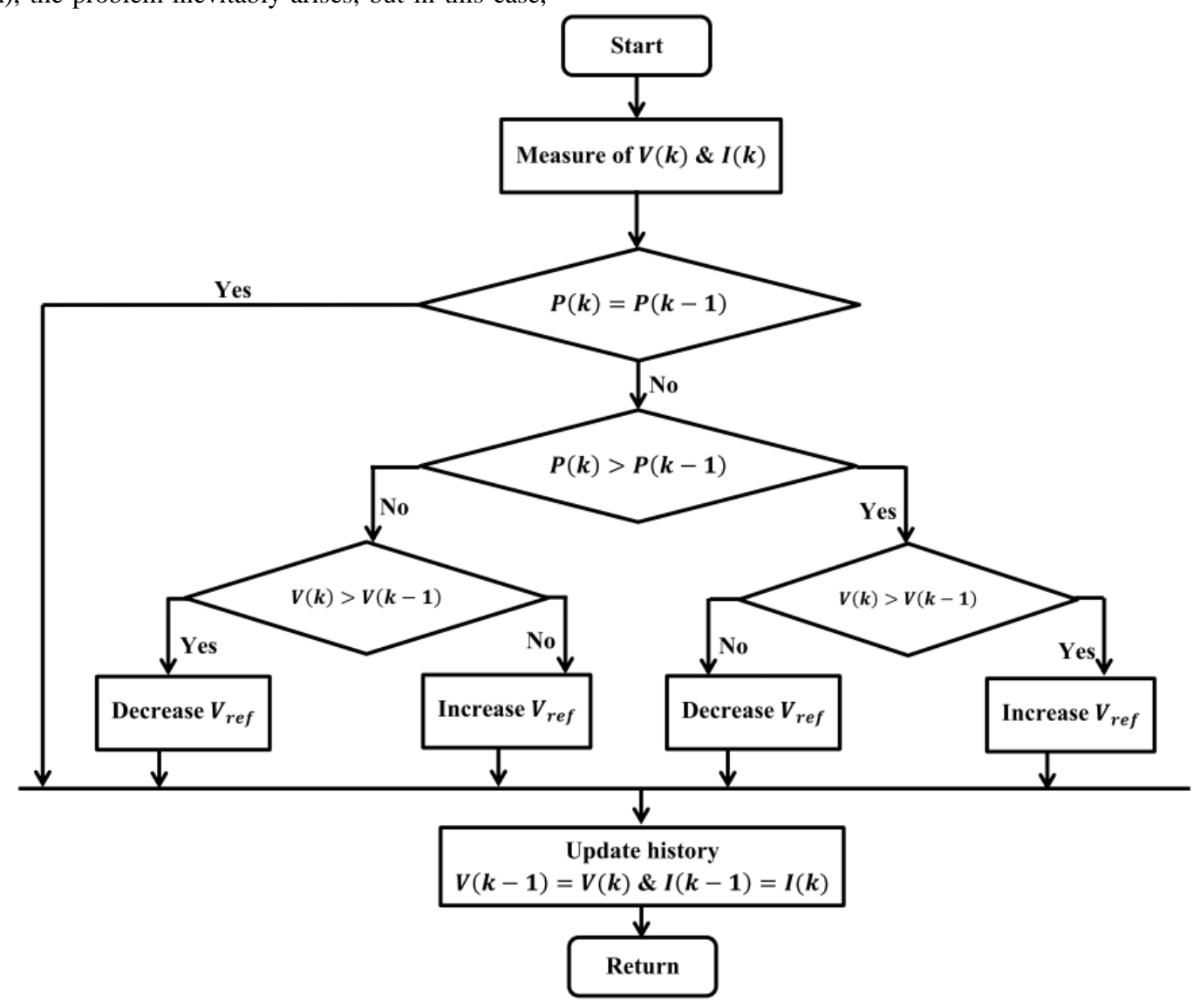

Fig 4 : Flow chart of (P\&O) MPPT [4] 
The 'P\&O' method is generally the most used because of its simplicity and ease of implementation. As the name implies, this method works by disrupting the system and observing the impact on the power output of the (GPV) $\left(\frac{d p}{d v}>0\right)$. So, it is clear that the disturbance has moved the operating point to the (MPPT). The (P\&O) algorithm will continue to trouble the tension in the same direction. However, if the power decreases $\left(\frac{d p}{d v}<0\right)$, the algorithm will reverse the direction of the next disturbance. The process is repeated periodically until the (MPP) is reached. The system oscillates around the (MPP), causing power loss. The oscillation can be minimized by reducing the size of the perturbation. It is important to note that with the (P\&O) algorithm, the variable to be controlled can be either the current or tension of the (GPV) [12][13]. However, the ideal variable that characterizes the (MPP) is one that varies little during climatic change. This algorithm change is summarized in the flow chart of Figure 4 [14][15].

\section{SIMULATION RESULTS}

\subsection{Variations in the characteristics $(P / V)$ and $(I / V)$}

It is to be used the MATLAB software to simulate the behavior of (GPV). The model used to simulate the behavior of the (PV) generator can be used to simulate the behavior of (GPV) on a different climatic condition. The function used MATLAB for simulation, has allowed us to build a graphical interface for viewing changes in characteristics (I/V) and (P/V) according to climate changes.

- The power according to the voltage

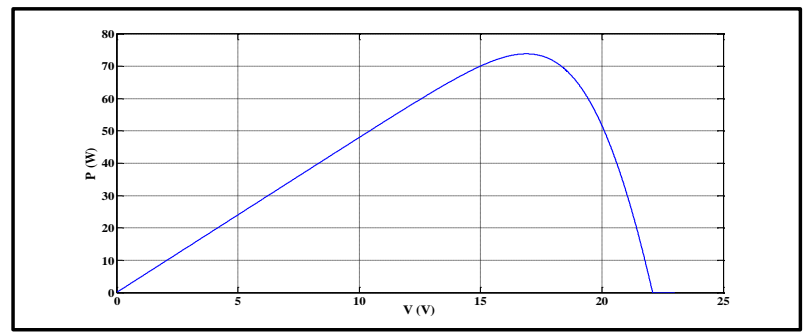

Fig 5 : Characteristic $P / V$

The characteristic $(P / V)$ of the module shows the importance of using the (MPPT) system to extract the maximum power that is equal in our model $\mathrm{P}_{\max }=75 \mathrm{~W}$.

The current according to the voltage

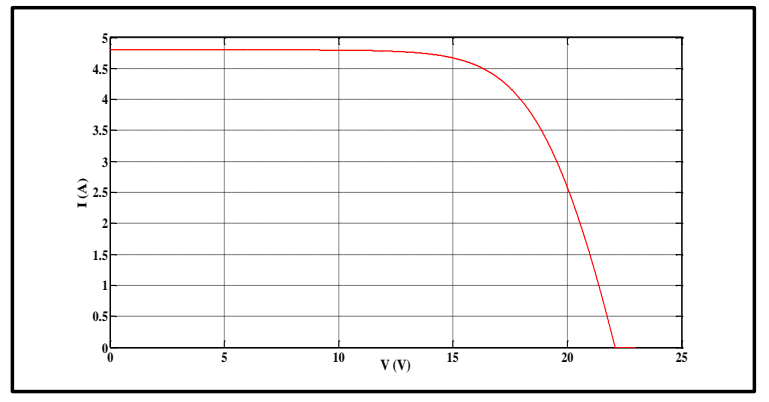

Fig 6 : Characteristic $I / V$

The characteristic $(I / V)$ of this module allows finding the maximum $P_{\text {max }}$ power that is the intersection of voltage $V_{M P P}$ and current $I_{M P P}$, from the curve:
$\mathrm{V}_{\mathrm{MPP}}=17 \mathrm{~V}$ and $\mathrm{I}_{\mathrm{MPP}}=4.41 \mathrm{~A}$. It is found that $\mathrm{P}_{\max }=$ $\mathrm{V}_{\mathrm{MPP}} \cdot \mathrm{I}_{\mathrm{MPP}}=75 \mathrm{~W}$, coinciding with the maximum power of our photovoltaic panel. These results justify the coincidence of our simulation case with the practice since the power rating of the panel photovoltaic $S P 75$ is $75 W$.

\subsection{Variations in the characteristics $(P / V)$ and $(I / V)$ based on climate change}

- Power as a function of the voltage : radiation variation

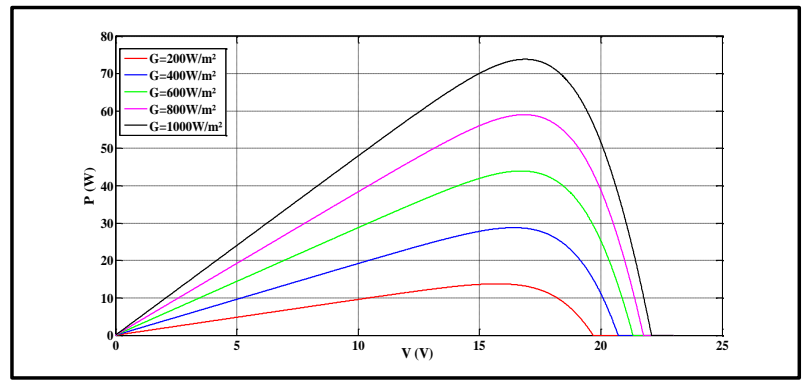

Fig 7 : The irradiation impact's on the characteristic $P / V$

The (GPV) is strongly influenced by the change in brightness and temperature. Indeed, in Figure 7, (GPV) is subject to changes in brightness when there is clear evidence of reduction in the power and the change of the maximum power point of MPPT. The decrease in power is proportional to the decrease of the illumination. (MPPT) for illumination of $1000 \mathrm{~W} / \mathrm{m}^{2}$ has a power that is equal to $75 \mathrm{~W}$. For an irradiation $800 \mathrm{~W} / \mathrm{m}^{2}$ the power is equal to $59 \mathrm{~W}$. For an illumination of $600 \mathrm{~W} / \mathrm{m}^{2}$, the power is equal to $45 \mathrm{~W}$. For illumination of $400 \mathrm{~W} / \mathrm{m}^{2}$, the power is equal to $28 \mathrm{~W}$. For an illumination of $200 \mathrm{~W} / \mathrm{m}^{2}$ the power is equal to $14 \mathrm{~W}$, therefore the power of the photovoltaic panel increases with the increased radiation. The voltage also increases with the radiation but the voltage remains constant (MPPT) for all values of the radiation was $V_{M P P}=17 \mathrm{~V}$.

- Power as a function of the voltage: the temperature variation

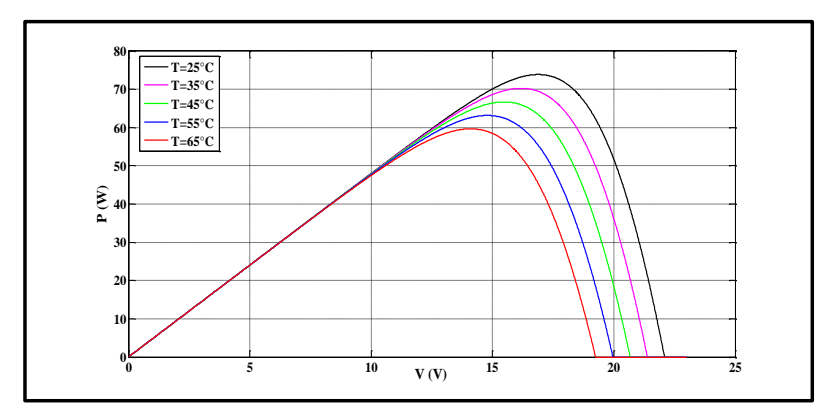

Fig 8 : The temperature impact's on the characteristic $\mathbf{P} / \mathbf{V}$

In this figure, the (GPV) is subjected to temperature variations at a constant brightness, but the (MPPT) voltage changes; there, also the point of maximum power (MPPT) changes. (MPPT) for a temperature of $25^{\circ} \mathrm{C}$ the power is equal to $75 \mathrm{~W}$. For a temperature of $35^{\circ} \mathrm{C}$ the power is $70 \mathrm{~W}$. For a temperature of $45^{\circ} \mathrm{C}$ the power is $66 \mathrm{~W}$. For a temperature of $55^{\circ} \mathrm{C}$ the power is $63 \mathrm{~W}$. For a temperature of $65^{\circ} \mathrm{C}$ the power is $60 \mathrm{~W}$. So if the temperature increases the value of the power of the photovoltaic panel decreases. 
- The current according to the voltage: The illumination change

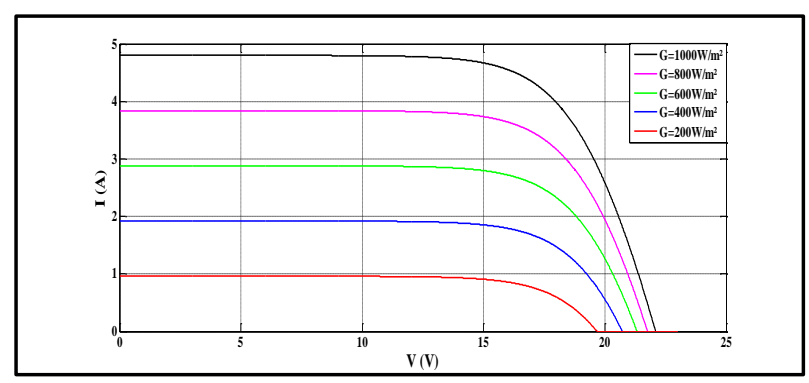

Fig 9 : The irradiation impact's on the characteristic I/V

The current/voltage characteristic of a solar panel has an extremum which varies with the illumination and the aging of the panel. When the illumination increases, the current of the photovoltaic panel increases. For an illumination of $1000 \mathrm{~W} / \mathrm{m}^{2}$ the current is $4,8 \mathrm{~A}$. For an irradiation $800 \mathrm{~W} / \mathrm{m}^{2}$ the current is $3,9 \mathrm{~A}$. For an illumination of $600 \mathrm{~W} / \mathrm{m}^{2}$ the current is $2,9 \mathrm{~A}$. For an illumination of $400 \mathrm{~W} / \mathrm{m}^{2}$ the current is $1,9 \mathrm{~A}$ and an illumination of $200 \mathrm{~W} / \mathrm{m}^{2}$ the current is $0,9 \mathrm{~A}$, while the voltage of the photovoltaic panel increases with illumination until it reaches stable values.

- The current according to the voltage: Variation of temperature

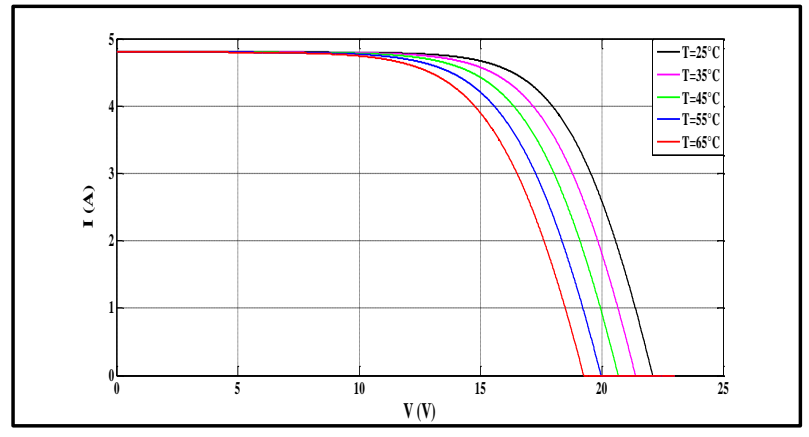

Fig 10 : The temperature impact's on the characteristic $I / V$

Since the energy of the band gap decreases with increasing temperature, there are more photons which have enough energy to create electron-hole pairs. Therefore, the current increases slightly, about $0,07 \% /{ }^{\circ} \mathrm{K}$. The voltage of $V$ circuit drop with the rise in the temperature .This decline is around $0,4 \% /{ }^{\circ} \mathrm{K}$. The power drops by $0,5 \% /{ }^{\circ} \mathrm{K}$. While tracking the (MPP) for a temperature of $25^{\circ} \mathrm{C}$, the current is $4,3 \mathrm{~A}$ is a voltage of $17 \mathrm{~V}$. For a temperature of $35^{\circ} \mathrm{C}$, the current is $4,2 \mathrm{~A}$ and a voltage of $17 \mathrm{~V}$. For a temperature of $45^{\circ} \mathrm{C}$, the current is $4,1 \mathrm{~A}$ and $15,5 \mathrm{~V}$ voltage. For a temperature of $55^{\circ} \mathrm{C}$, the current is $4,3 \mathrm{~A}$ and a voltage of $14,5 \mathrm{~V}$. For a temperature of $65^{\circ} \mathrm{C}$ the current is $4 \mathrm{~A}$ and a voltage of $14 \mathrm{~V}$.

\subsection{Simulation results by applying the MPPT control type Perturb \& Observe}

This section, is about presenting the simulation of different components of the chain (PV) conversion carried out under the Matlab/Simulink environment. The conversion chain consists of the following functional blocks :

- A photovoltaic module SP75 Type;

- A boost converter;
- A MPPT control (P\&O) Type;

- A load of $100 \Omega$;

- A step disruption 0,01 .

\section{Simulation Results}

1. For a constant illumination of $1000 \mathrm{~W} / \mathrm{m}^{2}$ and a temperature of $25^{\circ} \mathrm{C}$, the simulation results, under Matlab/Simulink environment, electric characteristics at the output of the panel and out of the controlled lift type chopper by (P\&O) MPPT control, it appears that:

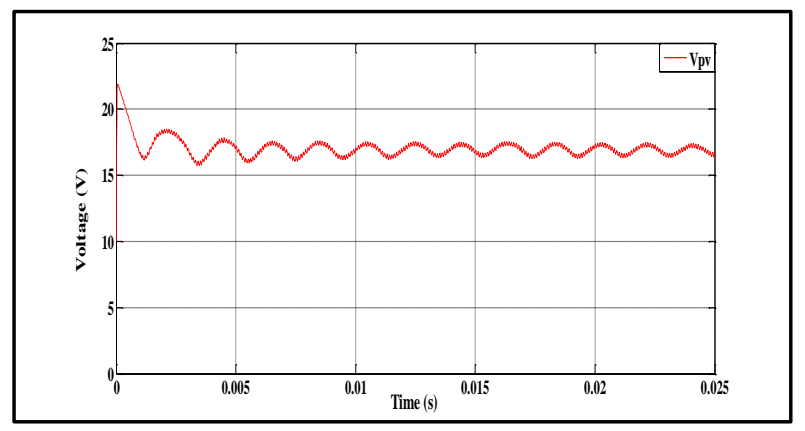

Fig 11.a

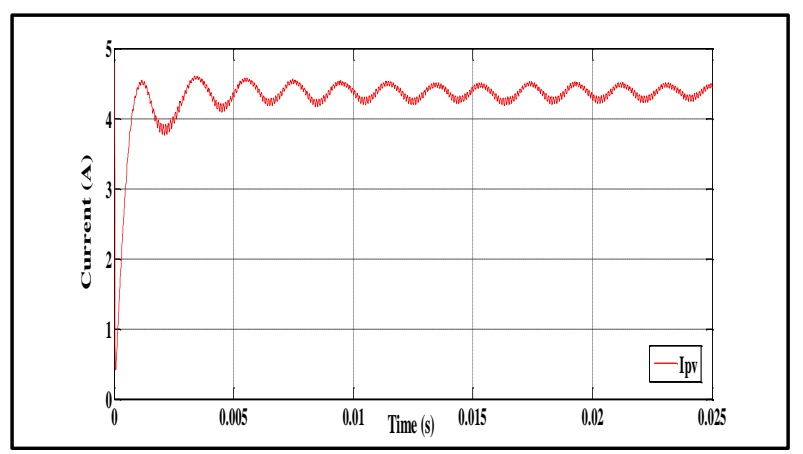

Fig 11.b

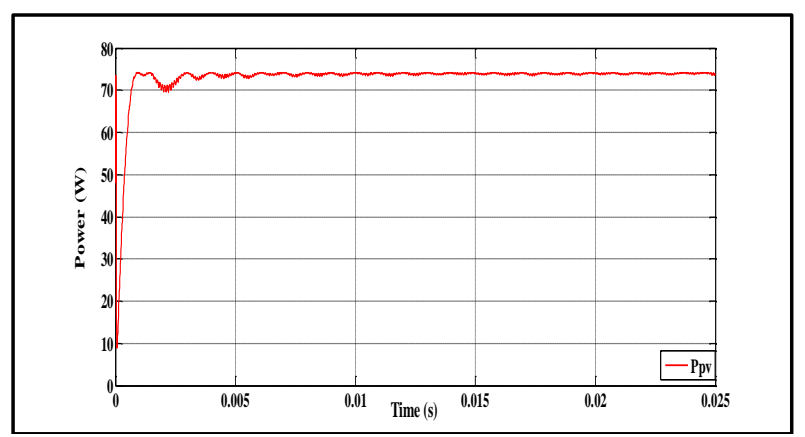

Fig 11.c

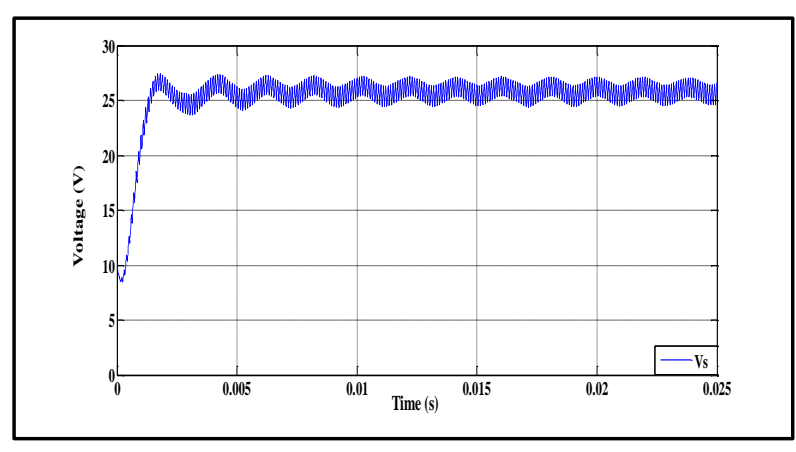

Fig 11.d 




Fig 11.e

Fig 11 : Voltages, currents and powers simulated as a function of time in the case of a boost converter controlled by the (P\&O) MPPT control with $R_{s}=10 \Omega$, $C_{s}=58,12 \mu F, C_{e}=11,9 \mu F, L=2 m H, f=10 k H z$ In Figure 11, are shown to the standard conditions $\left(\mathrm{G}=1000 \mathrm{~W} / \mathrm{m}^{2}\right.$ and $\left.\mathrm{T}=25^{\circ} \mathrm{C}\right)$, all the results of simulation in Matlab/Simulink.

It is to be noted from the set of results after a transient period of $1 \mathrm{~ms}$, that the controller rapidly oscillates the operating point around the point of the (MPP).

All electrical characteristics of the output of the panel respectively $\left(V_{p v}, I_{p v}, P_{p v}\right)$ and the output of the step-type chopper $\left(V_{s}, I_{s}\right)$ controlled by MPPT (P\&O) control oscillate around the values set out in our tender specifications :

-The output voltage of the photovoltaic generator oscillates around the value $17,5 \mathrm{~V}$;

-The current output of the (GPV) oscillates around the value $4,5 \mathrm{~A}$;

- The power output of the panel is stabilized at the value $74 \mathrm{~W}$

- The voltage and current supplied to the load are respectively $27 \mathrm{~V}$ and $2,7 \mathrm{~A}$

2. For this part, we compare simulations are compared by, convergence to the (MPP) on the power output of the $(\mathrm{PV})$ system, using the $(\mathrm{P} \& \mathrm{O}) \mathrm{MPPT}$ control.

- First, the temperature is maintained at a constant value equal to $25^{\circ} \mathrm{C}$, whereas the illumination $L$ is rapidly variable in the form of stairs with falling edges of relatively short durations; - Then, irradiation $G$ set to $1000 \mathrm{~W} / \mathrm{m}^{2}$, the command will be tested for a sudden change of temperature $T$ as staircase with falling edges.

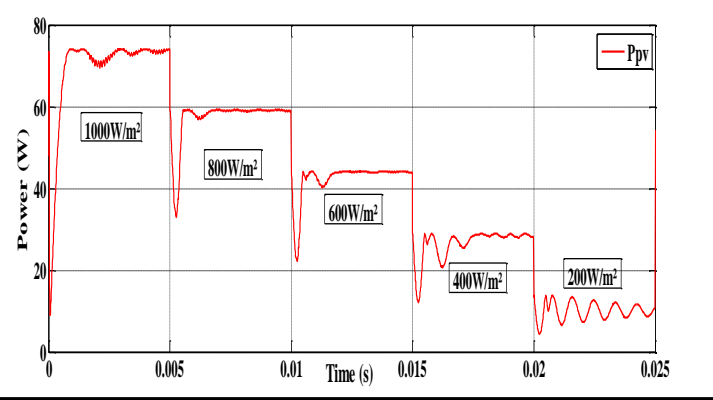

Fig 12.a

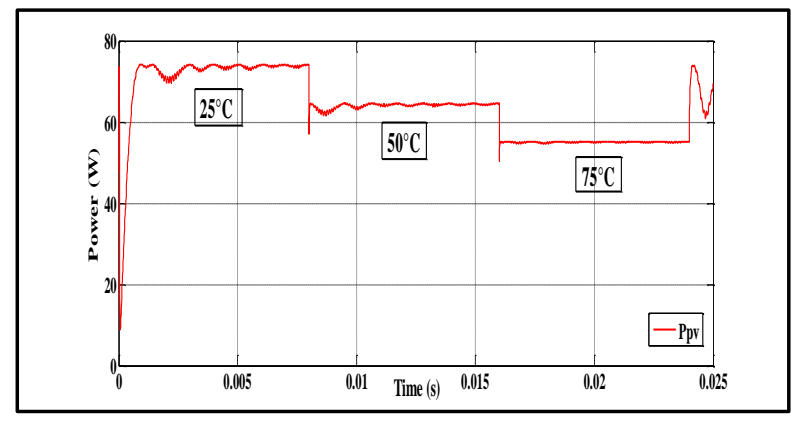

Fig 12.b

Fig 12 : Comparison of convergence to the PPM simulated power versus time using ( $\mathrm{P \& O}$ ) command under different conditions

From Figure 12, it is to be noted that after a transitional period of $1 \mathrm{~ms}$ duration (MPPT) control the operating point rises and stabilizes around the (MPP).

After the first change of illumination falling edge, it can be noted that the system rapidly converges to a new (MPP).

From the curve obtained (Figure (12.a)) by varying the lighting, it is to be noted that the time of transient increases with decreasing illumination before reaching a stabilization point of maximum power.

From Figure (12.b) it can be seen that the system controlled by the $(\mathrm{P} \& \mathrm{O})$ control immediately responds to the rapid variation of the temperature $T$, with a response time which decreases with the increase of temperature before reaching the steady state and the new (MPP) for each variation of Temperature.

It disrupts the $\alpha$ control signal with no small disturbance that is equal to 0,01 , but from the simulation results it can be seen from the various curves that the system keep up with the rapid changes of climatic conditions $T$ and $G$.

3. For this last part, working under standard conditions $\left(\mathrm{T}=25^{\circ} \mathrm{C}\right.$ and $\mathrm{G}=1000 \mathrm{~W} / \mathrm{m}^{2}$ ) will be about simulating the system by varying the load $\mathrm{R}$.

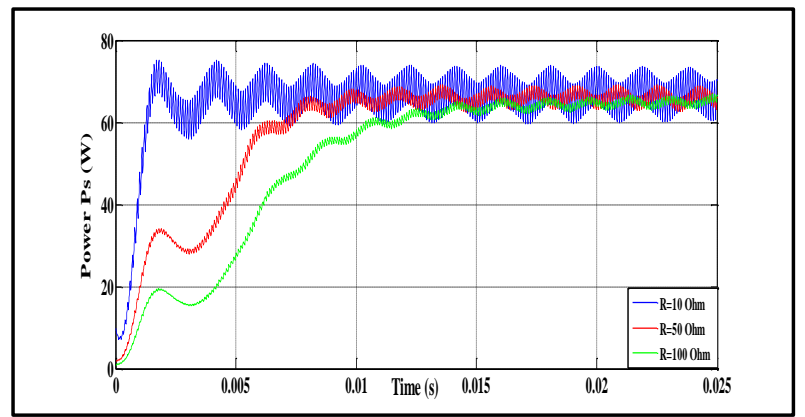

Fig 13 : Output power curve for different value of load

The Figure 13 shows three outputs power curves with changing load $R$. Following the analysis of the curves, it is shown that with increasing load $(\mathrm{R}=10 \Omega, \mathrm{R}=50 \Omega$, $\mathrm{R}=100 \Omega$ ) the time of the transitional regime increases respectively $(\mathrm{t}=1 \mathrm{~ms}, \mathrm{t}=9 \mathrm{~ms}, \mathrm{t}=14 \mathrm{~ms})$ and $(\mathrm{P} \& \mathrm{O})$ controller comes in all three cases to find the permanent state and converge towards a new (MPP). 
Ps $=75 \mathrm{~W}$ for $\mathrm{R}=10 \Omega$, Ps $=68.1 \mathrm{~W}$ for $\mathrm{R}=50 \Omega$ and $\mathrm{Ps}=65.7 \mathrm{~W}$ for $\mathrm{R}=100 \Omega$.

All the results obtained (Figure 11, 12, 13) confirmed that the boost convertor and $(\mathrm{P} \& \mathrm{O}) \mathrm{MPPT}$ control correctly perform their roles. The (MPPT) controller is adapted to the different conditions from the generator to the load, and converges to the point of maximum power.

The time of the transitory regime state indicates the speed controller $(\mathrm{P} \& \mathrm{O})$. This time depends on the width of the step of the disturbance and the reference voltage $V_{\text {ref }}$

\section{CONCLUSION}

This paper presented the improvement of $(\mathrm{P} \& \mathrm{O})$ MPPT method. The model is implanted using boost converter, simulated with MATLAB/SIMULNK. Through the results of the simulation using $S P 75 P V$ module, it is observed that the system completes the maximum power point tracking successfully for different temperature and irradiation.

The $(\mathrm{P} \& \mathrm{O})$ gives the optimum duty cycle as compared to Constant duty cycle control, to extract the maximum power from PV system.

The results show that for a period less than a $1 \mathrm{~ms}$ and varying in an automatic manner the cyclic ratio of the signal which controls the power converter switch the system converges to the conditions optimal regardless of weather conditions and load variation. These results, high cost, show that the use of the (MPPT) control improves a much higher yield of photovoltaic installations. The performance of a (GPV) is strongly influenced by the conditions weather, particularly solar radiation and the temperature of the $(\mathrm{PV})$ module. In this study, it's to be noted the use of the empirical model to simulate a diode operation of (PV) modules for different solar conditions and temperature [16]. The tool presented here has the advantage of being modular, which allows it to analyze and optimize the overall performance of the system for different electrical charges based on site meteorological data and thus a better understanding of (PV) systems. In general, to have the best connection between the (GPV) and the charge and produce an optimal power, the Maximum Power Point Tracking (MPPT) was designed and built. It forces the (GPV) to work at his Maximum Power Point (MPP), leading to an overall improvement of the electric conversion system performance. In the end, the study shows that the (MPPT) controller designed in this job properly performs its role. It regulates the power supplied by the (GPV) to its optimum value. The measurements of various electrical quantities show that the voltage at the output of the panel is $17.2 \mathrm{~V}$ and the power is optimal and it is equal to $75 \mathrm{~W}$.

\section{REFERENCES}

[1] Mrabti,T., El Ouariachi, M. , Tidhaf, B., et Kassmi, K. 2009«Caractérisation et modélisation fine du fonctionnement électrique des panneaux photovoltaïques » Université Mohamed Premier, Faculté des Sciences, Laboratoire 'LEPAS', Oujda, Maroc, Université Mohamed Premier, Ecole Nationale des Sciences Appliquées, ENSA, Oujda, Maroc.

[2] Aziz, A. Kassmi, K., Hamdaoui, M., olivie, F., 2007 « Conception et modélisation d'un système photovoltaïque optimisé par une commande analogique muni d'un circuit de détection de dysfonctionnement et de redémarrage du système » Université Mohamed Premier, Faculté des Sciences, Département de Physique, LEPAS,
Oujda, Maroc, Laboratoire d'Analyse et d'Architecture des Systèmes 'LAAS/CNRS', 7 avenue du Colonel Roche, 31 077, Toulouse, France.

[3] Mrabti, T., El Ouariachi, M., Kassmi, K., Olivié, F., et Bagui, F., 2008 «Conception, modélisation et réalisation d'un système photovoltaïque de moyenne puissance» Université Mohamed Premier, Faculté des Sciences, Département de Physique, 'LEPAS', Oujda, Maroc, Laboratoire d'Analyse et d'Architecture des Systèmes, 'LAAS/CNRS',7 avenue du Colonel Roche, 31077, Toulouse, France, Ecole d'Ingénieurs, Centre d'Etudes Supérieures Industrielles, 'CESI', Mont Saint Aignan, France.

[4] Zerhouni, F.Z., 1996 «Adaptation Optimale d'une Charge à un Générateur Photovoltaïque », Mémoire de Magister, Institut d'Electronique.

[5] M.Boukli-Hacene Omar «Conception et réalisation d'un générateur photovoltaïque muni d'un convertisseur MPPT pour une meilleure gestion énergétique» universite Abou-Bakr Tlemcen Faculté de technologie.

[6] Kassmi, K., Hamdaoui, M., olivie, F., 2007 «Conception et modélisation d'un système photovoltaïque adapté par une commande MPPT analogique», Université Mohammed premier, Faculté des sciences. Laboratoire d'Analyse et d'Architecture des Systèmes.

[7] Messenger, R.A., 2004 «J. Ventre, Photovoltaic Systems Engineering (Second Edition)», CRC Press.

[8] Brahimi (MEM), 2001 «Situation des énergies renouvelables en Algérie». Conférence sur la maîtrise de l'énergie et de l'environnement dans un contexte d'économie de marche.

[9] DenHerder, T., 2006 «Design and Simulation of Photovoltaic Super System Using Simulink», California Polytechnic State University.

[10] Matlab/Simulink

[11] Pierre Petit, 2011 «Optimisation du transfert d'énergie dans les systèmes photovoltaïques», Université de Metz.

[12] Nattorn Pongratananukul, 2005 "Analysis and Simulation Tools for Solar Array Power Systems", University of Central Florida.

[13] Trishan Esram, Student Member, IEEE, and Patrick L. Chapman, Senior Member, IEEE, 2006 "Comparison of Photovoltaic Array Maximum Power Point Tracking Techniques", IEEE TRANSACTIONS ON ENERGY CONVERSION.

[14] Xiao,W. 2003 "A Modified Adaptative Hill Climbing Maximum Power Point Tracking (MPPT) Control Method For Photovoltaic Power Systems", The University of British Columbia.

[15] Akihiro, Oi. 2005 "Design and Simulation of Photovoltaic Water Pumping System", Faculty of California Polytechnic State University.

[16] A. Ould Mohamed Yahya , A. Ould Mahmoud, I. Youm «Etude et modélisation d'un générateur photovoltaïque» Centre de Recherche Appliquée aux Energies Renouvelables 'CRAER', Université de Nouakchott, 
Mauritanie. Laboratoire des Semi-conducteurs et d'Energie Solaire, 'LASES', Faculté des Sciences et Techniques, Université Cheikh Anta DIOP, Dakar, Sénégal. Centre d'Etudes et de Recherches sur les Energies Renouvelables 'CERER',B.P. 476, Dakar, Sénégal . Revue des énergies renouvelables Vol $11 \mathrm{~N}^{\circ} 4$ (2008) (Juillet 2008-Septembre 2008).

\section{AUTHOR'S PROFILE}

\section{Pr. Dr. Abdelhadi EL MOUDDEN}

Doctor of Science from The National Polytechnic Institute of Toulouse (INPT) in 1993 - FRANCE.

$\mathrm{He}$ is now a professor in the National School of Electricity and Mechanics (ENSEM), University Hassan II, Casablanca, Morocco.

Since 2006, he has been a member of Laboratory Computing, Systems and Renewable Energies (LISER), Team Analysis and Command of Electrical Energy Systems (ACSEE). His research interests include Dynamic Simulations of Electric Machinery, Simulation and Optimization of Renewable Energy Systems. He has presented and published many articles in scientific journals and conferences.

\section{Ikram BOHADRIA : Doctoral student}

I am a doctoral student preparing a doctoral thesis in the National School of Electricity and Mechanics (ENSEM), University Hassan II, Casablanca. Team Analysis and Command of Electrical Energy Systems (ACSEE) Laboratory of Computing, Systems and Renewable Energy (LISER).

On June 2013, I got an engineering diploma specialized in Electrical and Renewable Energy in ENSA. My doctoral thesis is about Modelling and simulation of production and energy storage of an autonomous hybrid system coupling a photovoltaic array and a wind turbine.

\section{Abdelali AARIB : Doctoral student}

I am in the process of preparing a doctoral thesis in the National School of Electricity and Mechanics (ENSEM), University Hassan II, Casablanca, Morocco.

Team Analysis and Command of Electrical Energy Systems (ACSEE) - Laboratory of Computing, Systems and Renewable Energy (LISER).

On July 2011 I got a diploma on Master specialized in renewable energy and energy systems in the Faculty of Science, University Hassan II, Casablanca, Morocco. My doctoral thesis discusses the optimization of the electrical energy produced by the double-fed asynchronous machine used in wind power. I presented many communications at international scientific conferences. I attended several international scientific congresses and I participated in the publication of numerous articles in scientific journals.

\section{Widad DRIOUICH CORBIER : Doctoral student}

I am an electrical engineer and now a PHD student preparing a doctoral thesis in the National engineering School of Electricity and Mechanics (ENSEM), University Hassan II, Casablanca, Morocco; Inside the Laboratory of Computing, Systems and Renewable Energy (LISER). My doctoral thesis is about storage of electrical energy produced by an hybrid system (solar and wind).

\section{Pr. Dr. Abdelhamid HMIDAT}

Doctorate of 3rd cycle in electric engineering.

Since 1986 he is professor in the National School of Electricity and Mechanics (ENSEM), University Hassan II, Casablanca, Morocco.

Since 2006, he has been a member of Research Group: Electrical Systems Team.

His research interests include Dynamic Simulations of Electric Machinery, Simulation and Optimization of Resonant Converters. He has presented and published many articles in scientific journals and conferences. 